\title{
Spatial variability in bacterial abundance and other microbial components in the NW Iberian margin during relaxation of a spring upwelling event
}

\author{
F. G. Figueiras ${ }^{1, *}$, M. K. Zdanowski ${ }^{2}$, B. G. Crespo ${ }^{1}$ \\ ${ }^{1}$ Instituto de Investigacións Mariñas (CSIC), Eduardo Cabello 6, 36208 Vigo, Spain \\ ${ }^{2}$ Department of Antarctic Biology, Polish Academy of Sciences, 02-141 Warsaw, Ustrzycka 10, Poland
}

\begin{abstract}
The spatial distribution of heterotrophic bacterioplankton abundance (BA) and bacterial colony forming units (CFU) plus additional biological (abundance of autotrophic and heterotrophic pico- and nanoplankton, diatoms and chlorophyll a concentration), physical (temperature and salinity) and chemical (nutrient concentrations) variables were investigated along the Galician coast (NW Iberia) after the cessation of a strong spring upwelling event. BA and abundance of autotrophic and heterotrophic pico- and nanoplankton tended to increase with distance from the coast, while diatoms were more abundant near to the coast. Over $70 \%$ of the variance in BA could be explained by a regression equation with 3 variables, in which abundance of autotrophic nanoflagellates $(61 \%)$ and abundance of heterotrophic nanoflagellates $(7 \%)$ accounted for $68 \%$ of the total explained variability. The remaining $2 \%$ was related to chlorophyll a variations. Variability in CFU abundance (67\%) was attributable to a negative relationship with salinity and to a lesser but significant degree by a positive relationship with diatom abundance. These data suggest that a number of mechanisms regulated bacterial abundance in the NW Iberian margin after spring upwelling: CFU was related to continental influence and diatoms, and BA was associated with the biomass of autotrophic nanoflagellates. The relationships between BA, autotrophic nanoflagellates (ANF) and chlorophyll a (Chl) in the oceanic samples suggest that a change from bottom-up to top-down control of BA would occur

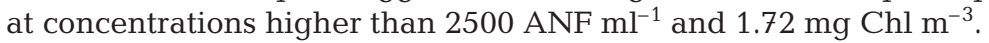

KEY WORDS: Bacterial abundance $\cdot$ Phytoplankton $\cdot$ Upwelling relaxation $\cdot$ NW Iberia

\section{INTRODUCTION}

Bacteria are important components of marine ecosystems, as they play a fundamental role in marine biogeochemical cycles by metabolising both autochthonous and allochthonous organic matter and converting particulate organic matter (POM) and dissolved organic matter (DOM) into bacterial biomass (Fuhrman 1992, Smith et al. 1992, del Giorgio \& Cole 1998). Despite much recent progress in marine microbiology (Gasol \& Duarte 2000, Li 2002, Li et al. 2004) and interest in the importance of microbial food web processes, the mechanisms that determine bacterial abundance in marine waters are still poorly under- stood. Since coastal upwelling systems are among the areas with the highest POM and DOM production in the ocean (Wollast 1998, Álvarez-Salgado et al. 1999), an analysis of factors that influence bacterial abundance appears fundamental to improving our current understanding of these ecosystems.

Shelf waters of the Galician margin (NW Iberia) experience considerable hydrographic variability due to the influence of upwelling and the presence of 4 deep tectonic bays (Rías Baixas) (Fig. 1). These waters are thus ideal sites for studying factors that may affect bacterial abundance (e.g. Zdanowski \& Figueiras 1997, 1999). Production in the NW Iberian margin is largely influenced by upwelling events that enhance primary 


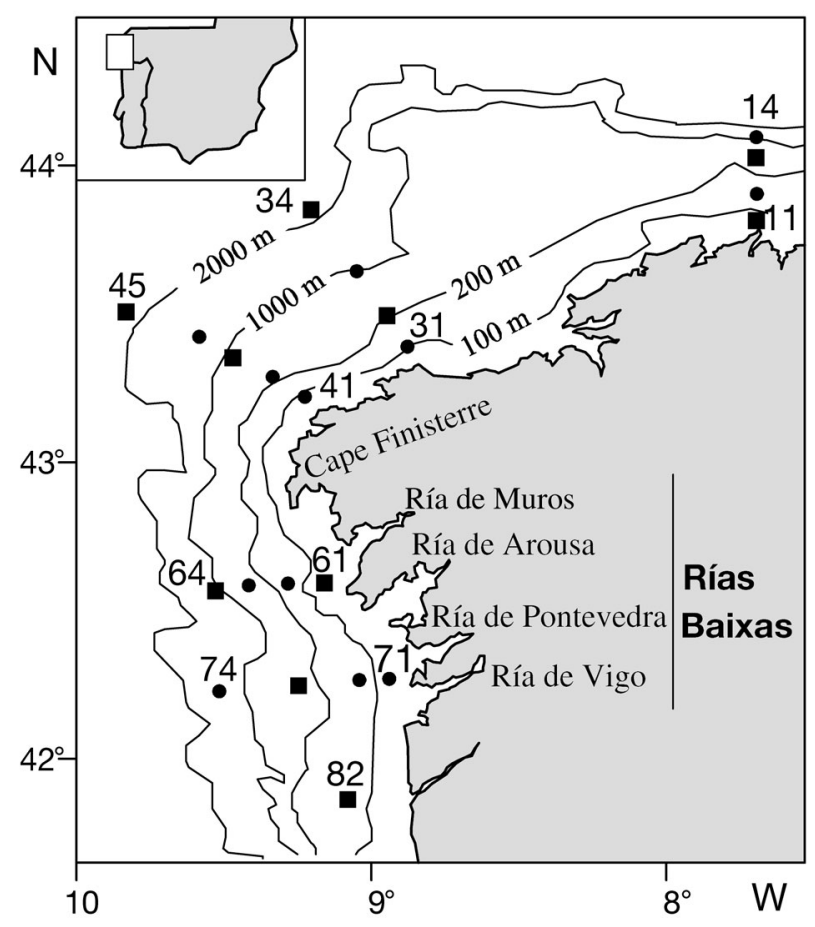

Fig. 1. Location of stations. Black squares represent stations at which colony forming unit (CFU) bacteria were grown. The shelf break coincides approximately with the $200 \mathrm{~m}$ isobath

production over the shelf (Tenore et al. 1995, Teira et al. 2001, Joint et al. 2002, Tilstone et al. 2003) and inside the Rías Baixas (Fraga 1976, Hanson et al. 1986, Tilstone et al. 1999, Moncoiffé et al. 2000), leading to the accumulation of DOM in surface waters (Alvarez-Salgado et al. 1999). As particulate and dissolved matter is exported to the shelf from the Rías Baixas (Prego et al. 1990, Alvarez-Salgado et al. 2000), bacterial abundance in the Galician shelf waters can be affected by the import of bacteria from the Rías or by in situ production. Bacterial secondary production is also affected by other biota and hydrographic variability in the region (Zdanowski \& Figueiras 1997, 1999, Barbosa et al. 2001). Although some aspects of bacterial processes in Galician coastal waters, such as the bacteria response to upwelling pulses and their impact on DOC fluxes have been described (Hanson et al. 1986, Tenore et al. 1995, Barbosa et al. 2001, Morán et al. 2002, Valencia et al. 2003), there are few data relating bacterial abundance to other physical, chemical and biological variables. Bacterial abundance can be affected by the physical (e.g. temperature and salinity), chemical (e.g. nutrient concentrations) and biological (e.g. abundance of other microbial plankton components) environment. Therefore, studies relating these variables to bacterial abundance can provide information about the main factors controlling bacterial populations (Gasol \& Duarte 2000, Li et al. 2004, Ning et al. 2005).
The study described here was carried out in Galician shelf and ocean waters in spring after a strong upwelling event had subsided, and coincided with the first phytoplankton blooms of the season. The main objective of this paper is to determine which factors account for distribution of bacterial abundance.

\section{MATERIALS AND METHODS}

Horizontal and vertical distributions of total bacterioplankton and the colony forming fraction were investigated off the Galician coast between 42 and $44^{\circ} \mathrm{N}$, and from 7 to $10^{\circ} \mathrm{W}$ (Fig. 1), between 10 and 14 May 1991 during the GALICIA XI cruise aboard the RV 'Investigador-S'. Total bacterial abundance (BA) was determined at 21 stations on 5 cross-shore sections, while colony forming units (CFU) were enumerated at 9 of the 21 stations plus 1 other (Stn 82, Fig. 1). Samples for bacterial work were collected in an ethanol rinsed Van Dorn-type 51 bottle at 0, 10, 20, 30, 50 and $80 \mathrm{~m}$ depth and, exceptionally, at $100 \mathrm{~m}$ where depth permitted. Thereafter, subsamples of $\sim 100 \mathrm{ml}$ were immediately transferred to sterile, opaque, screw-capped glass bottles and maintained at $\sim 5^{\circ} \mathrm{C}$ until processed on board within $1 \mathrm{~h}$.

Samples of $10 \mathrm{ml}$ were fixed with buffered $0.2 \mu \mathrm{m}$ filtered formaldehyde ( $2 \%$ final concentration) and stained with DAPI at $0.1 \mu \mathrm{g} \mathrm{ml} \mathrm{m}^{-1}$ final concentration for $5 \mathrm{~min}$ (Porter \& Feig 1980), and then filtered through $0.2 \mu \mathrm{m}$ black Millipore-Isopore filters. The filters were frozen immediately and then analysed by epifluorescence microscopy within 2 mo of collection. BA and the abundance of Synechococcus type cyanobacteria (SYN), autotrophic and heterotrophic pico$(\leq 2 \mu \mathrm{m})$ and nanoflagellates (2 to $20 \mu \mathrm{m})$ were determined on the same sample. Autotrophic organisms were enumerated under blue light excitation where SYN were distinguished by their yellow colour and autotrophic pico- (APF) and nanoflagellates (ANF) by red-orange colour. Bacteria and heterotrophic pico(HPF) and nanoflagellates (HNF) were enumerated under excitation with UV light. We are aware that mixotrophic flagellates could not be reliably identified with these count conditions. At least 300 bacteria and 100 cells of the other microbial components were counted. Diatoms (DIAT) were counted in $100 \mathrm{ml}$ samples fixed with Lugol's iodine using an inverted microscope.

CFU were enumerated in $100 \mu$ l of seawater spread on Bacto Marine Agar 2216 (ZoBell 1941). Plates were incubated for up to $15 \mathrm{~d}$ at $24^{\circ} \mathrm{C}$. From each sampling point, 3 replicates were performed, from which mean CFU abundance was calculated. The coefficient of variation was below $10 \%$. 

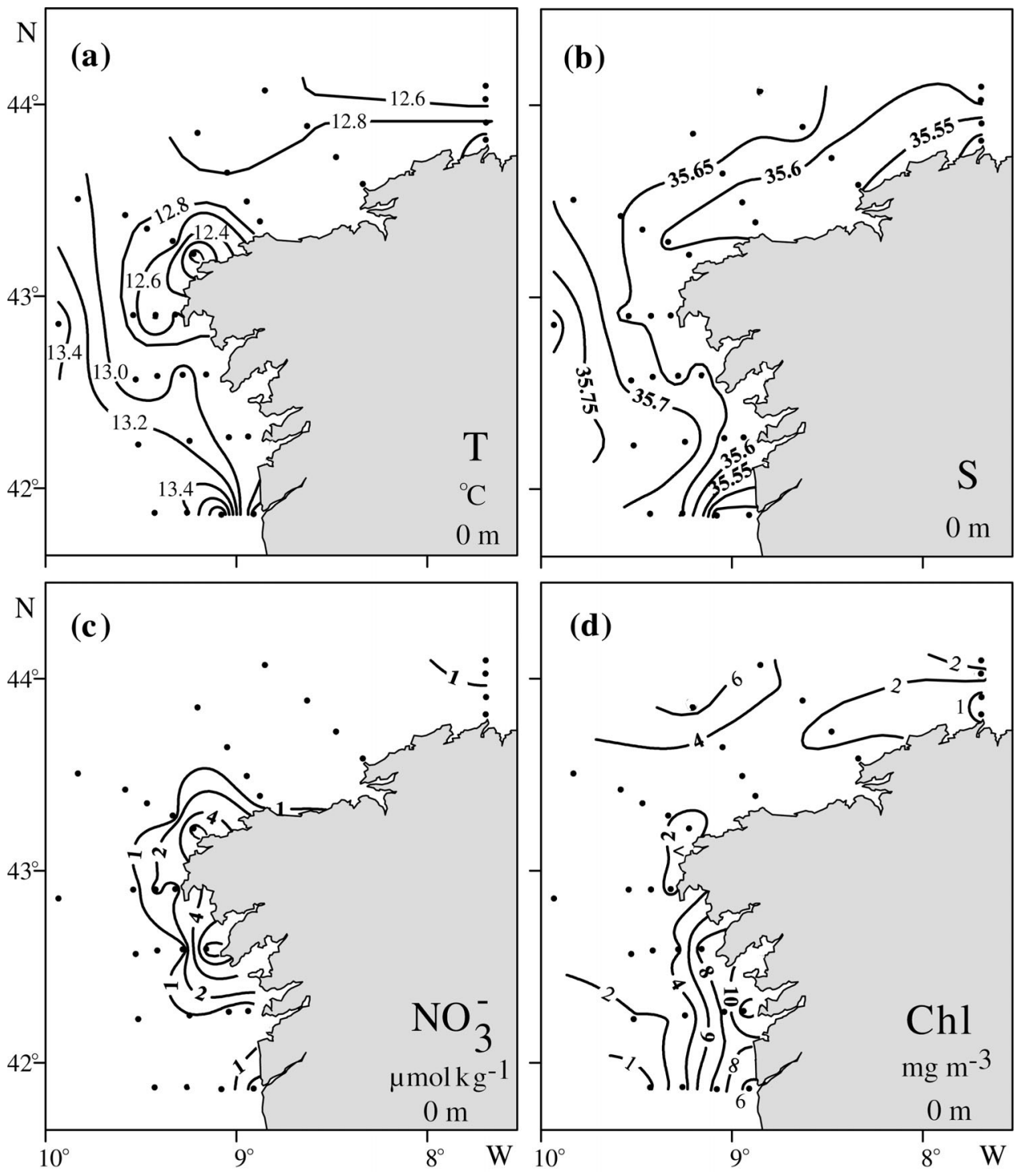

Fig. 2. Horizontal distributions at the sea surface of (a) temperature, (b) salinity, (c) nitrate concentration and (d) chlorophyll concentration

Seawater temperature $\left({ }^{\circ} \mathrm{C}\right)$ and salinity (S) were determined by CTD. Chlorophyll a (Chl) concentration was determined by fluorometry (Yentsch \& Menzel 1963) after low vacuum pressure filtration of $100 \mathrm{ml}$ seawater samples through $25 \mathrm{~mm}$ Whatman GF/F filters and overnight pigment extraction in $90 \%$ acetone. Nutrients were measured in an auto-analyser; nitrate $\left(\mathrm{NO}_{3}\right)$ after reduction to nitrite $\left(\mathrm{NO}_{2}\right)$ through a $\mathrm{Cu} / \mathrm{Cd}$ column (Hansen \& Grasshoff 1983) with modifications after Mouriño \& Fraga (1985), silica $\mathrm{Si}(\mathrm{OH})_{4}$ and phosphates $\left(\mathrm{PO}_{4}\right)$ following Hansen \& Grasshoff (1983) and ammonium $\left(\mathrm{NH}_{4}\right)$ according to Grasshoff \& Johansen (1972). Additional CTD casts and Chl and nutrient determinations were conducted at other stations for mapping purposes (Figs. $2 \& 3$ ).
General trends in the spatial distribution of the variables along-shore (north to south transects), distance from land (position of the stations in transects) and depth of samples (surface to $100 \mathrm{~m}$ ) were assessed with the aid of the Spearman rank order correlation analysis using discrete depth data. Product-moment correlation was employed to identify significant relationships among variables. The dependence of bacterial abundance on the other variables was assessed using regression analyses. Multiple regressions were used to identify which variables were most important in regulating BA and CFU variability. For regression analysis, the abundances and Chl values were log-transformed to correct for normal distributions. Multiple regressions 
were run in a forward mode and tested at the $5 \%$ level of significance.

\section{RESULTS}

\section{Hydrography and biology}

Hydrographic conditions during the cruise were described by Castro et al. (1994). In summary, relaxation of an upwelling event caused the shoreward migration of surface water from oceanic stations, blocking the outflow of low salinity water (Fig. 2b) with high Chl values (Fig. 2d) from the Rías Baixas. Chl concentrations were also high ( $>6 \mathrm{mg} \mathrm{m}^{-3}$; Fig. $2 \mathrm{~d}$ ) at the surface of the oceanic stations in the northwest corner
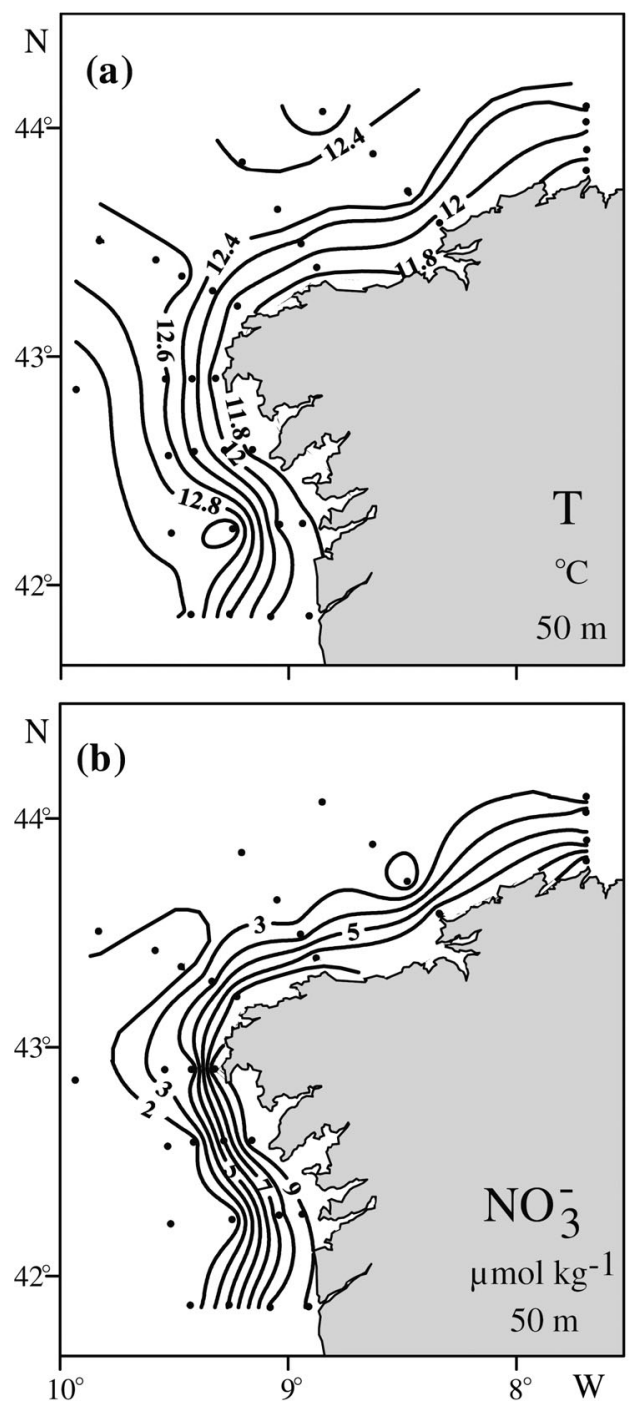

Fig. 3. Horizontal distributions at $50 \mathrm{~m}$ depth of (a) temperature and (b) nitrate concentration of the sampling area where nutrients were depleted (Fig. 2c). Upwelling, however, was still detected in the vicinity of Cape Finisterre, where low temperatures, high nutrient and relatively low $\mathrm{Chl}$ concentrations were recorded in surface waters (Fig. 2a,c,d). Clear signals of intense upwelling remained at $50 \mathrm{~m}$ along a narrow band near the coast as indicated by temperature and nitrate concentration (Fig. 3a,b).

Biological, physical and chemical variables in the upper $100 \mathrm{~m}$ of the water column are presented in Table 1. Biological and chemical variability was high during the $4 \mathrm{~d}$ cruise. The greatest variability in the biological components occurred in diatom abundance (coefficient of variation, $\mathrm{CV}=703 \%$ ). Variability was also high ( $\mathrm{CV}>100 \%)$ for CFU abundance, other autotrophic components (SYN, APF, ANH) and Chl, while BA and HPF showed lower variation ( $\mathrm{CV}<42 \%)$. Variability of HNF $(\mathrm{CV}=65 \%)$ was moderate. The range of variation of temperature was small $\left(<2^{\circ} \mathrm{C}\right)$ due to mixing forced by upwelling in a water column that was still weakly stratified. Salinity also showed little variability. Nutrient variability was influenced by the presence of upwelled waters at $\sim 50 \mathrm{~m}$ with high nutrient levels (Fig. 3b) and their exhaustion in the surface (Fig. 2b).

Biological variability was not only due to variations with depth, since cross-shore and along-shore variations were considerable (Fig. 4). APF and ANF, which were positively correlated $(r=0.86, p<0.001)$, were

Table 1. Mean, standard deviation (SD), and minima and maxima of bacterial abundance (BA), colony forming unit bacteria (CFU), diatoms (DIAT), Synechococcus 'type' cyanobacteria (SYN), autotrophic pico- and nanoflagellates (APF, ANF), heterotrophic pico- and nanoflagellates (HPF, HNF), chlorophyll a concentration (Chl), seawater temperature $(\mathrm{T})$, salinity $(\mathrm{S})$ and concentrations of ammonium $\left(\mathrm{NH}_{4}\right)$, nitrate $\left(\mathrm{NO}_{3}\right)$, phosphate $\left(\mathrm{PO}_{4}\right)$ and silica $\mathrm{Si}(\mathrm{OH})_{4}$ during the cruise GALICIA XI. CFU: $\mathrm{n}=35$, DIAT: $\mathrm{n}=147$, other variables: $\mathrm{n}=148$

\begin{tabular}{|lccc|}
\hline Variable & Mean $\pm \mathrm{SD}$ & Minimum & Maximum \\
\hline $\mathrm{BA}\left(\times 10^{6} \mathrm{ml}^{-1}\right)$ & $1.5 \pm 0.6$ & 0.5 & 2.8 \\
$\mathrm{CFU}\left(\times 10^{2} \mathrm{ml}^{-1}\right)$ & $5.04 \pm 8.21$ & 0.62 & 43.47 \\
$\mathrm{DIAT}\left(\times 10^{2} \mathrm{ml}^{-1}\right)$ & $12.22 \pm 85.9$ & 0 & 889.32 \\
$\mathrm{SYN}\left(\times 10^{2} \mathrm{ml}^{-1}\right)$ & $16.43 \pm 22.22$ & 0.19 & 86.17 \\
$\mathrm{APF}\left(\times 10^{2} \mathrm{ml}^{-1}\right)$ & $43.62 \pm 44.04$ & 0.93 & 259.33 \\
$\mathrm{ANF}\left(\times 10^{2} \mathrm{ml}^{-1}\right)$ & $28.49 \pm 28.91$ & 0.18 & 147.38 \\
$\mathrm{HPF}\left(\times 10^{2} \mathrm{ml}^{-1}\right)$ & $85.59 \pm 35.65$ & 14.29 & 188.13 \\
$\mathrm{HNF}\left(\times 10^{2} \mathrm{ml}^{-1}\right)$ & $24.98 \pm 16.23$ & 2.6 & 79.62 \\
$\mathrm{Chl}\left(\mathrm{mg} \mathrm{m}^{-3}\right)$ & $2.13 \pm 2.18$ & 0.07 & 12.71 \\
$\mathrm{~T}\left({ }^{\circ} \mathrm{C}\right)$ & $12.4 \pm 0.4$ & 11.5 & 13.3 \\
$\mathrm{~S}$ & $35.653 \pm 0.051$ & 35.490 & 35.762 \\
$\mathrm{NH}_{4}\left(\mu \mathrm{mol} \mathrm{kg}^{-1}\right)$ & $0.84 \pm 0.37$ & 0.26 & 2.05 \\
$\mathrm{NO}_{3}\left(\mu \mathrm{mol} \mathrm{kg}^{-1}\right)$ & $3.13 \pm 3.13$ & 0 & 10.48 \\
$\left.\mathrm{PO}_{4}(\mu \mathrm{mol} \mathrm{kg})^{-1}\right)$ & $0.24 \pm 0.19$ & 0.036 & 0.67 \\
$\mathrm{Si}(\mathrm{OH})_{4}\left(\mu \mathrm{mol} \mathrm{kg}^{-1}\right)$ & $1.86 \pm 1.10$ & 0.34 & 5.15 \\
\hline
\end{tabular}


more abundant in the open ocean than in shelf waters, and in the northern than in the western oceanic stations, where they significantly contributed to the high Chl values found there (see also Fig. 2d). SYN (data not shown), which were positively correlated with APF and ANF ( $\mathrm{r} \geq 0.79, \mathrm{p}<0.001)$ showed a similar distribution to that of APF + ANF. High Chl concentrations in the shelf waters in general (Fig. 4) and in front of the Rías Baixas in particular (Fig. 2) were due to diatoms (Fig. 4). Heterotrophs (HPF, HNF and bacteria) were
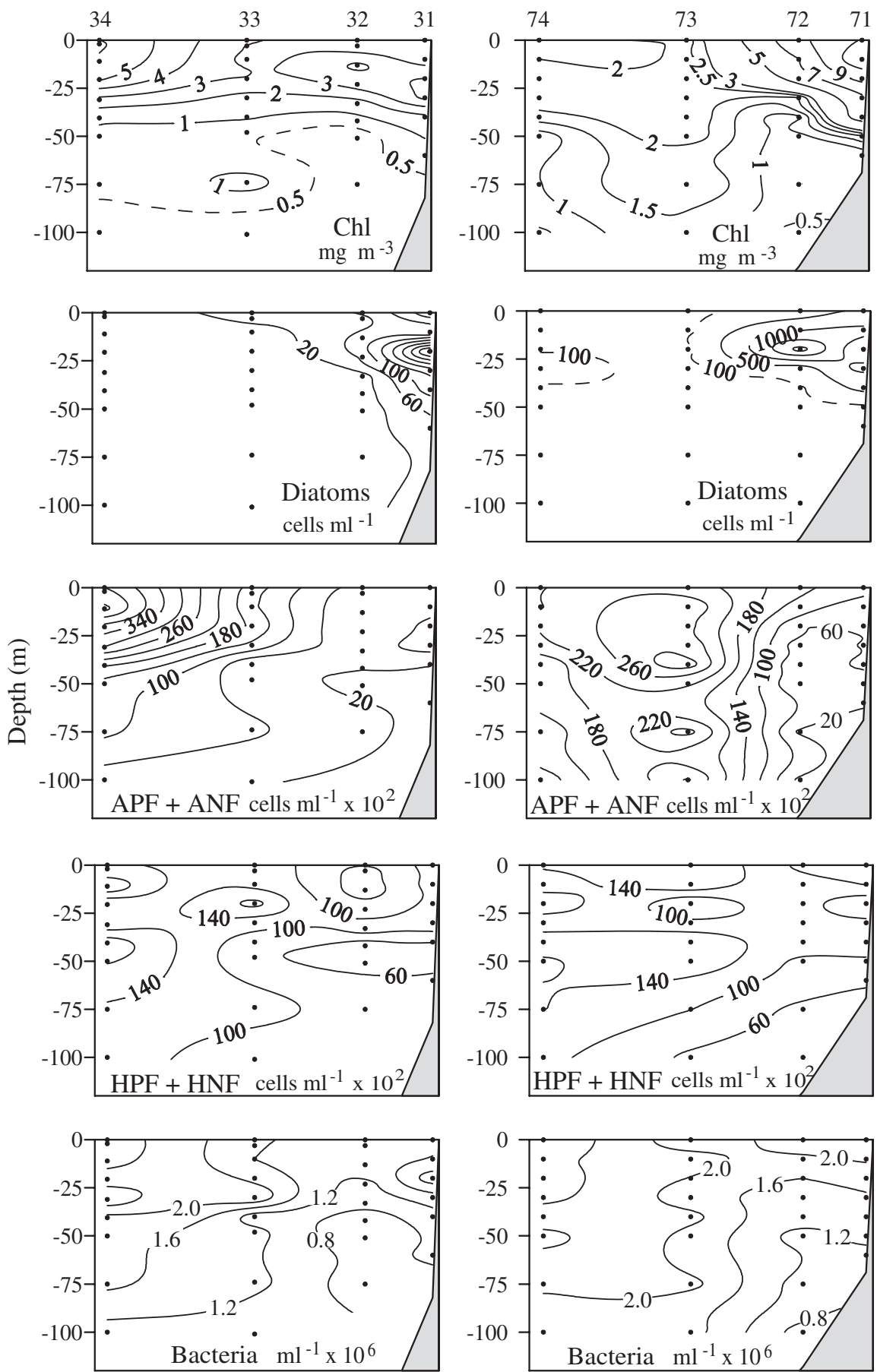

Fig. 4. Vertical distributions of chlorophyll a concentration (Chl) and abundances of diatoms, autotrophic pico- and nanoplankton $(\mathrm{APF}+\mathrm{ANF})$, heterotrophic pico- and nanoplankton (HPF + HNF) and bacteria, along 2 cross-shelf transects in the northern (Stns 31 to 34$)$ and in the western (Stns 71 to 74 ) coast 
more uniformly distributed than autotrophs (APF + ANF) (Fig. 4). HPF and HNF were positively correlated ( $\mathrm{r}=0.52, \mathrm{p}<0.001$ ). In contrast, CFU (data not shown) showed higher abundance in coastal waters.

Table 2. Spearman rank order correlation matrix for the relationship between biological, physical and chemical variables with sampling points from north to south transects, distance from land and depth (surface to $100 \mathrm{~m}$ ) during the cruise GALICIA XI. Variables: BA (bacterial abundance), CFU (colony forming bacteria), DIAT (diatoms), SYN (Synechococcus type cyanobacteria), APF (autotrophic picoflagellates), ANF (autotrophic nanoflagellates), HPF (heterotrophic picoflagellates), HNF (heterotrophic nanoflagellates), Chl (chlorophyll a concentration), $\mathrm{T}$ (seawater temperature), $\mathrm{S}$ (salinity), $\mathrm{NH}_{4}$ (ammonium), $\mathrm{NO}_{3}$ (nitrate), $\mathrm{PO}_{4}$ (phosphate), $\mathrm{Si}(\mathrm{OH})_{4}$ (silica). CFU: $\mathrm{n}=35$, DIAT: $\mathrm{n}=147$, other variables: $\mathrm{n}=148$. Significance level : ${ }^{*} \mathrm{p}<0.05,{ }^{* *} \mathrm{p}<0.01,{ }^{* * *} \mathrm{p}<0.001$ )

\begin{tabular}{|lccc|}
\hline Variable & $\begin{array}{c}\text { Transect } \\
(\mathrm{N}-\mathrm{S})\end{array}$ & $\begin{array}{c}\text { Distance } \\
\text { from land }\end{array}$ & Depth \\
\hline $\mathrm{BA}$ & $0.42^{* * *}$ & $0.42^{* * *}$ & $-0.42^{* * *}$ \\
$\mathrm{CFU}$ & $-0.38^{*}$ & $-0.78^{* * *}$ & -0.12 \\
$\mathrm{DIAT}$ & $0.33^{* * *}$ & $-0.57^{* * *}$ & $-0.38^{* * *}$ \\
$\mathrm{SYN}$ & $0.22^{* *}$ & $0.66^{* * *}$ & $-0.17^{* *}$ \\
$\mathrm{APF}$ & $0.26^{* *}$ & $0.57^{* * *}$ & $-0.34^{* * *}$ \\
$\mathrm{ANF}$ & $0.18^{*}$ & $0.49^{* * *}$ & $-0.47^{* * *}$ \\
$\mathrm{HPF}$ & 0.04 & $0.32^{* * *}$ & $-0.22^{* *}$ \\
$\mathrm{HNF}$ & $0.25^{* *}$ & $0.27^{* *}$ & $-0.34^{* * *}$ \\
$\mathrm{Chl}$ & $0.26^{* *}$ & 0.01 & $-0.71^{* * *}$ \\
$\mathrm{~T}$ & $0.23^{* *}$ & $0.44^{* * *}$ & $-0.58^{* * *}$ \\
$\mathrm{~S}$ & $0.60^{* * *}$ & $0.55^{* * *}$ & $0.24^{* *}$ \\
$\mathrm{NH} H_{4}$ & 0.06 & $0.25^{* *}$ & $0.27^{* * *}$ \\
$\mathrm{NO}_{3}$ & 0.02 & $-0.29^{* * *}$ & $0.66^{* * *}$ \\
$\mathrm{PO}_{4}$ & -0.03 & $-0.28^{* * *}$ & $0.67^{* * *}$ \\
$\mathrm{Si}(\mathrm{OH})_{4}$ & $-0.21^{*}$ & $-0.24^{* *}$ & $0.45^{* * *}$ \\
\hline
\end{tabular}

The results of the Spearman rank order correlation analysis (Table 2) summarise these general trends in the distribution of the variables. BA, diatoms and salinity tended to increase from north to south. Six variables (SYN, APF, ANF, HNF, Chl and temperature) also shared a positive trend to increase from north to south, while CFU and $\mathrm{Si}(\mathrm{OH})_{4}$ showed a negative trend (Table 2). Regardless of this along-shore gradient, costal-ocean gradients were more obvious (Table 2). Whilst BA tended to increase with distance from the shore, CFU and diatoms decreased with distance from the coast. The rest of the biological variables, with the exception of $\mathrm{Chl}$, also increased with distance from land. Temperature and salinity also increased with distance from the coast, while nutrients decreased; except for ammonium. BA and most of the biological variables decreased with depth. The uniform vertical distribution of CFU is remarkable. Salinity and nutrient concentrations increased and temperature decreased with depth.

\section{Relationships between bacteria and other biological and environmental variables}

Significant positive product-moment correlations (Table 3) were found between BA and pico-nanoplankton components plus Chl, temperature and salinity. Pico-nanoplankton and $\mathrm{Chl}$ were also positively correlated with temperature. Nutrients, ammonium excluded, showed negative correlations with BA, piconanoplankton and Chl. All pico-plankton components showed positive correlations among them. Diatoms, which were only weakly correlated with $\mathrm{Chl}$ and

Table 3. Pearson product-moment correlation matrix of biological, physical and chemical variables. BA (bacterial abundance), CFU (colony forming bacteria), DIAT (diatoms), SYN (Synechococcus type cyanobacteria), APF (autotrophic picoflagellates), ANF (autotrophic nanoflagellates), HPF (heterotrophic picoflagellates), HNF (heterotrophic nanoflagellates), Chl (chlorophyll a concentration), $\mathrm{S}$ (salinity), $\mathrm{T}$ (seawater temperature), $\mathrm{NH}_{4}$ (ammonium), $\mathrm{NO}_{3}$ (nitrate), $\mathrm{PO}_{4}$ (phosphate), $\mathrm{Si}(\mathrm{OH})_{4}$ (silica). $\mathrm{CFU}$ : $\mathrm{n}=35$, DIAT: $\mathrm{n}=147$, other variables: $\mathrm{n}=148$. Significance level: ${ }^{*} \mathrm{p}<0.05,{ }^{* *} \mathrm{p}<0.01,{ }^{* * *} \mathrm{p}<0.001$

\begin{tabular}{|c|c|c|c|c|c|c|c|c|c|c|c|c|c|c|}
\hline & BA & $\mathrm{CFU}$ & DIAT & SYN & APF & ANF & HPF & HNF & Chl & $\mathrm{S}$ & $\mathrm{T}$ & $\mathrm{NH}_{4}$ & $\mathrm{NO}_{3}$ & $\mathrm{PO}_{4}$ \\
\hline CFU & -0.15 & & & & & & & & & & & & & \\
\hline DIAT & 0.04 & $0.38^{*}$ & & & & & & & & & & & & \\
\hline SYN & $0.66^{* * *}$ & $-0.37^{*}$ & -0.05 & & & & & & & & & & & \\
\hline $\mathrm{APF}$ & $0.66^{* * *}$ & -0.33 & -0.01 & $0.85^{* * *}$ & & & & & & & & & & \\
\hline ANF & $0.71^{* * *}$ & -0.25 & 0.04 & $0.79^{* * *}$ & $0.86^{* * *}$ & & & & & & & & & \\
\hline $\mathrm{HPF}$ & $0.43^{* * *}$ & 0.05 & 0.04 & $0.16^{*}$ & $0.19^{*}$ & $0.27^{* *}$ & & & & & & & & \\
\hline HNF & $0.50^{* * *}$ & 0.09 & 0.09 & $0.24^{* *}$ & $0.25^{* *}$ & $0.26^{* *}$ & $0.52^{* * *}$ & & & & & & & \\
\hline $\mathrm{Chl}$ & $0.47^{* * *}$ & 0.26 & $0.20^{*}$ & 0.10 & $0.35^{* * *}$ & $0.38^{* * *}$ & $0.19^{*}$ & $0.27^{* *}$ & & & & & & \\
\hline S & $0.44^{* * *}$ & $-0.53^{* *}$ & -0.01 & $0.69^{* * *}$ & $0.54^{* * *}$ & $0.42^{* * *}$ & 0.06 & 0.12 & 0.00 & & & & & \\
\hline $\mathrm{T}$ & $0.72^{* * *}$ & -0.07 & 0.04 & $0.61^{* * *}$ & $0.57^{* * *}$ & $0.62^{* * *}$ & $0.35^{* * *}$ & $0.55^{* * *}$ & $0.33^{* * *}$ & $* 0.28^{* * *}$ & & & & \\
\hline $\mathrm{NH}_{4}$ & -0.05 & -0.05 & $-0.17^{*}$ & $0.13^{*}$ & 0.06 & -0.02 & 0.01 & 0.04 & $-0.16^{*}$ & $0.22^{* *}$ & 0.01 & & & \\
\hline $\mathrm{NO}_{3}$ & $-0.60^{* * *}$ & 0.16 & -0.08 & $-0.42^{* * *}$ & $-0.46^{* * *}$ & $-0.52^{* * *}$ & $-0.38^{* * *}$ & $-0.46^{* * *}$ & $-0.28^{* * *}$ & $*-0.02$ & $-0.86^{* * *}$ & -0.02 & & \\
\hline $\mathrm{PO}_{4}$ & $-0.62^{* * *}$ & 0.13 & -0.10 & $-0.41^{* * *}$ & $-0.47^{* * *}$ & $-0.53^{* * *}$ & $-0.40^{* * *}$ & $-0.49^{* * *}$ & $-0.35^{* * *}$ & * -0.01 & $-0.86^{* * *}$ & 0.05 & $0.99^{* * *}$ & \\
\hline $\mathrm{Si}(\mathrm{OH})_{4}$ & $-0.54^{* * *}$ & 0.10 & -0.13 & $-0.28^{* * *}$ & $-0.34^{* * *}$ & $-0.35^{* * *}$ & $-0.37^{* * *}$ & $-0.48^{* * *}$ & $-0.31^{* * *}$ & $*-0.06$ & $-0.78^{* * *}$ & 0.06 & $0.91^{* * *}$ & $0.92^{* * *}$ \\
\hline
\end{tabular}


Table 4. Significant regressions $(p<0.001)$ relating bacterial abundance (BA, cells $\mathrm{ml}^{-1}$ ) to other biological, physical and chemical variables. SYN (Synechococcus type cyanobacteria), APF (autotrophic picoflagellates), ANF (autotrophic nanoflagellates), HPF (heterotrophic picoflagellates), HNF (heterotrophic nanoflagellates), Chl (chlorophyll a concentration), $\mathrm{S}$ (salinity), $\mathrm{T}$ (seawater temperature), $\mathrm{NO}_{3}$ (nitrate), $\mathrm{PO}_{4}$ (phosphate), $\mathrm{Si}(\mathrm{OH})_{4}$ (silica). Cell abundance, cells $\mathrm{ml}^{-1}$; $\mathrm{Chl}$,

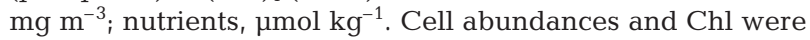
log-transformed to compute regressions statistics. Number of samples $=148$. The model II slope provides an estimate of the true slope when there is error in the independent variable

\begin{tabular}{|lcccc|}
\hline $\begin{array}{l}\text { Independent } \\
\text { variable }\end{array}$ & $\mathrm{r}^{2}$ & Slope $\pm \mathrm{SE}$ & Y-int. $\pm \mathrm{SE}$ & $\begin{array}{c}\text { Model II } \\
\text { slope }\end{array}$ \\
\hline $\log \mathrm{SYN}$ & 0.45 & $0.19 \pm 0.02$ & $5.62 \pm 0.05$ & 0.28 \\
$\log \mathrm{APF}$ & 0.59 & $0.32 \pm 0.02$ & $5.04 \pm 0.08$ & 0.42 \\
$\log \mathrm{ANF}$ & 0.61 & $0.28 \pm 0.02$ & $5.25 \pm 0.06$ & 0.36 \\
$\log \mathrm{HPF}$ & 0.22 & $0.44 \pm 0.07$ & $4.41 \pm 0.27$ & 0.94 \\
$\log \mathrm{HNF}$ & 0.38 & $0.41 \pm 0.04$ & $4.78 \pm 0.14$ & 0.67 \\
$\log \mathrm{Chl}$ & 0.48 & $0.28 \pm 0.02$ & $6.10 \pm 0.1$ & 0.40 \\
$\mathrm{~S}$ & 0.16 & $1.57 \pm 0.3$ & $-49.93 \pm 10.64$ & 3.93 \\
$\mathrm{~T}$ & 0.51 & $0.33 \pm 0.03$ & $2.01 \pm 0.34$ & 0.46 \\
$\mathrm{NO}_{3}$ & 0.38 & $-0.04 \pm 0.004$ & $6.25 \pm 0.02$ & -0.06 \\
$\mathrm{PO}_{4}$ & 0.40 & $-0.68 \pm 0.07$ & $6.30 \pm 0.02$ & -1.09 \\
$\mathrm{Si}_{4}(\mathrm{OH})_{4}$ & 0.31 & $-0.10 \pm 0.01$ & $6.32 \pm 0.3$ & -0.18 \\
\hline
\end{tabular}

ammonium, showed positive correlation with CFU. Salinity and SYN were negatively correlated with CFU.

Although regressions between BA and each one of the correlated variables were significant (Table 4), forward multiple stepwise regression identified only 3 significant biological variables (ANF, HNF, and Chl) that explained $70 \%$ of the BA variability (Table $5 \mathrm{a}$ ). ANF alone accounted for $61 \%$ of the BA variability, while $\mathrm{HNF}$ and Chl explained 7 and $2 \%$, respectively. Temperature, however, which alone accounted for $51 \%$ of the BA variability (Table 4), did not appear as a significant factor in the multiple regression. As BA could be regulated by the resources supplied by autotrophs and predation by HNF as suggested by the multiple regression, single pairs of the relationship between BA and the significant variables in the multiple regression were explored using the original nontransformed data. The relationships between BA and ANF and HNF were exponential, rising to a maximum value (Fig. 5a,b). BA and Chl showed 2 types of relationships (Fig. 5c); exponential for the ocean stations and linear for coastal waters. From the relationship between ANF and Chl (Fig. 5d) it can be deduced that the contribution of ANF to Chl was 8 times higher in the ocean with the absence of diatoms $\left(2.14 \times 10^{9} \mathrm{ANF}\right.$ $\mathrm{mg} \mathrm{Chl}^{-1}$ ) than in the coastal waters with high diatom abundance $\left(0.27 \times 10^{9} \mathrm{ANF} \mathrm{mg} \mathrm{Chl}^{-1}\right)$.

The explained variability in CFU abundance (67\%) could be described by a negative relationship with
Table 5. Significant multiple stepwise regressions of (a) logarithm of bacterial abundance (LogBA) and (b) logarithm of colony forming units (Log CFU). $\beta$ : standardised coefficient of regression, $\mathrm{p}$ : level of significance of the slopes in the regression equation. Log ANF (logarithm of ANF abundance, cells $\mathrm{ml}^{-1}$ ), LogHNF (logarithm of HNF abundance, cells $\mathrm{ml}^{-1}$ ), Log Chl (logarithm of chlorophyll a concentration, $\mathrm{mg} \mathrm{m}^{-3}$ ), $\mathrm{S}$ (salinity), Log Diat (logarithm of diatom abundance, cells $\mathrm{ml}^{-1}$ )

\begin{tabular}{|lccc|}
\hline \multicolumn{1}{|c}{$\beta$} & $\mathrm{p}$ & $\%$ explained variance \\
\hline (a) & & & \\
LogBA $(\mathrm{n}=148)$ & & $\mathrm{r}^{2}=0.70, \mathrm{p}<0.001$ \\
Log ANF & $0.49 \pm 0.07$ & $<0.001$ & 61 \\
Log HNF & $0.27 \pm 0.05$ & $<0.001$ & 7 \\
Log Chl & $0.21 \pm 0.07$ & $<0.01$ & 2 \\
(b) & & & \\
Log CFU $(\mathrm{n}=35)$ & & $\mathrm{r}^{2}=0.67, \mathrm{p}<0.001$ \\
S & $-0.53 \pm 0.11$ & $<0.001$ & 45 \\
LogDiat & $0.49 \pm 0.11$ & $<0.001$ & 22 \\
\hline
\end{tabular}

salinity $(45 \%)$, and to a lesser extent ( $22 \%$ ) by a positive relationship with diatom abundance (Table 5b). Single relationships (Fig. 6a,b) accounted for similar percentages (40 to $45 \%$ ) of CFU variability.

\section{DISCUSSION}

In general, estimates of BA averaging $10^{6} \mathrm{ml}^{-1}$ are similar to those found in shelf waters off the NW Iberian margin under upwelling conditions (Barbosa et al. 2001, Morán et al. 2002, Valencia et al. 2003) and in the Ría de Vigo (Zdanowski \& Figueiras 1997, Morán et al. 2002). Conversely, estimates of CFU at each sampling point averaged $10^{2} \mathrm{ml}^{-1}$, much lower (10 to $10^{2}$ times) than in the Ría de Vigo in general (Zdanowski \& Figueiras 1999). Total bacterial numbers (BA) varied less than CFU, as previously reported for the estuarine Ría de Vigo (Zdanowski \& Figueiras 1997, 1999).

\section{Control of heterotrophic bacterioplankton abundance}

The cause of variations in bacterial biomass in the ocean is a controversial question, since both bottom-up and top-down control mechanisms might act simultaneously at different rates. Bacterial growth can be regulated by temperature and the availability of organic and inorganic nutrients (Cole et al. 1988, Currie 1990, White et al. 1991, Barbosa et al. 2001), whereas predation and viral lyses limit biomass (Sherr \& Sherr 1987, Weimbauer \& Peduzzi 1995, Proctor \& Fuhrman 1999). Studies of factors regulating bacterial production in the Equatorial Pacific Ocean (Kirchman \& Rich 1997) sug- 

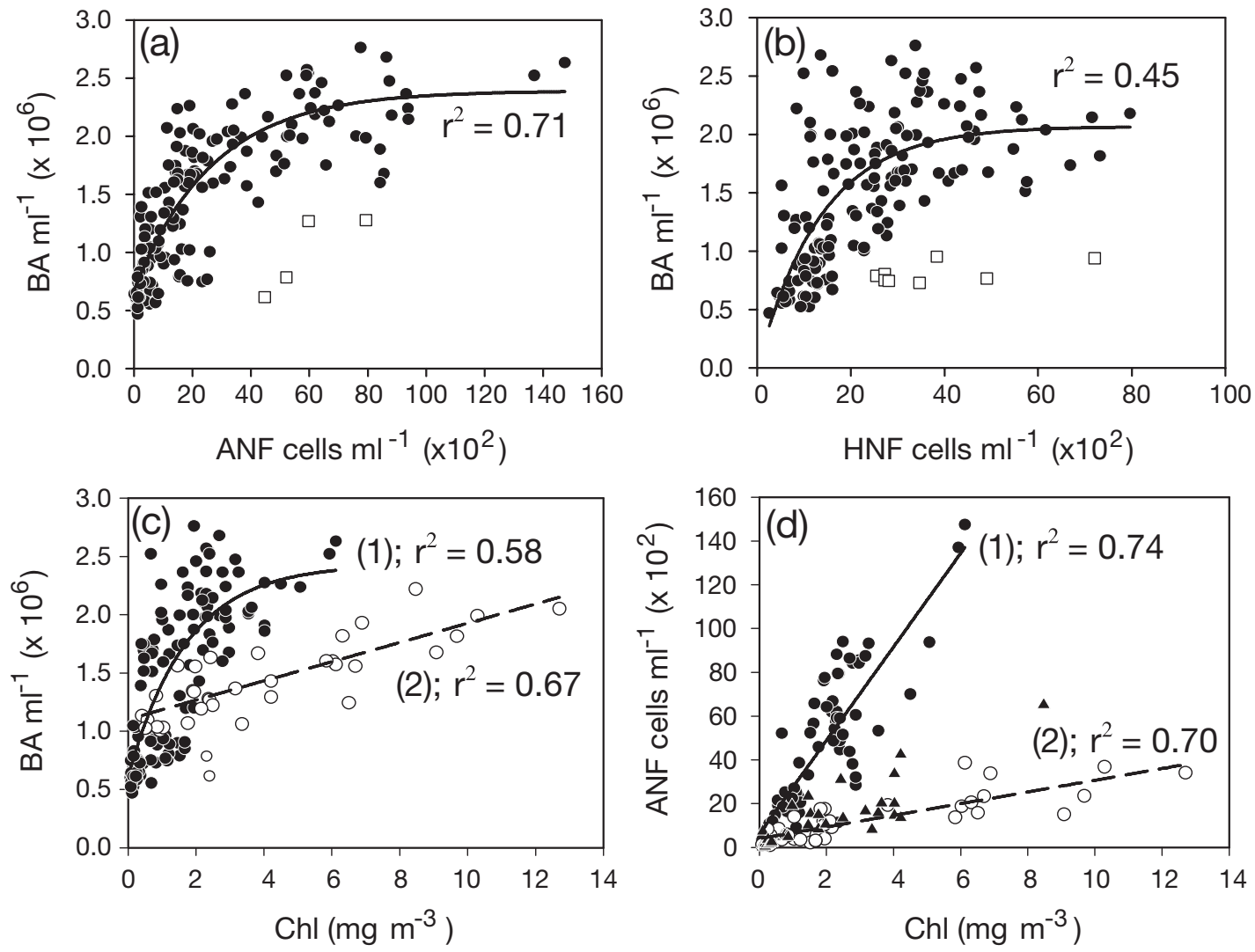

Fig. 5. Scatter plots of (a) ANF abundance vs. bacterial abundance, (b) HNF abundance vs. bacterial abundance, (c) chlorophyll a concentration vs. bacterial abundance and (d) chlorophyll a concentration vs. ANF abundance. Exponential relationships in (a) and (b) without the points marked with open squares are $Y=(0.65 \pm 0.07)+(1.64 \pm 0.09)[1-\exp (-0.04 \pm 0.007) X]$ and $Y=$ $(2.07 \pm 0.09)[1-\exp (-0.07 \pm 0.009) X]$ respectively; the equations including these points, $Y=(0.65 \pm 0.08)+(1.52 \pm 0.1)[1-$ $\exp (-0.05 \pm 0.008) X], \mathrm{r}^{2}=0.62$ for $(\mathrm{a})$ and $Y=(1.91 \pm 0.009)[1-\exp (-0.08 \pm 0.01) X], \mathrm{r}^{2}=0.34$ for (b), are not substantially different. There were no differences between coastal and ocean samples in (a) and (b). In (c) and (d) (O) = coastal stations; $(\bullet)=$ ocean stations. Fitted lines in (c) are (1): $Y=(0.61 \pm 0.11)+(1.83 \pm 0.20)[1-\exp (-0.58 \pm 0.17) X]$ and $(2): Y=(1.10 \pm 0.05)+(0.08 \pm 0.01) X$. Fitted lines in (d) are (1): $Y=(6.22 \pm 3.30)+(21.36 \pm 1.49) X$ and $(2): Y=(3.99 \pm 1.37)+(2.67 \pm 0.3) X$. Linear regressions in $(d)$ correspond to ocean samples $(\bullet)$ with dominance of ANF and coastal samples (O) with dominance of diatoms; $(\mathbf{\Delta})=$ samples that were not used for computations owing to no clear dominance of ANF or diatoms. Exponential relationships in (a), (b) and (c) $Y=$ $Y_{0}+a\left(1-\mathrm{e}^{-b \mathrm{X}}\right)$ allow estimation of the initial slopes for $\boldsymbol{X}_{\rightarrow 0}=a \times b$, and the $X$ value for saturated $Y, X \mathrm{~S}=1 / b$
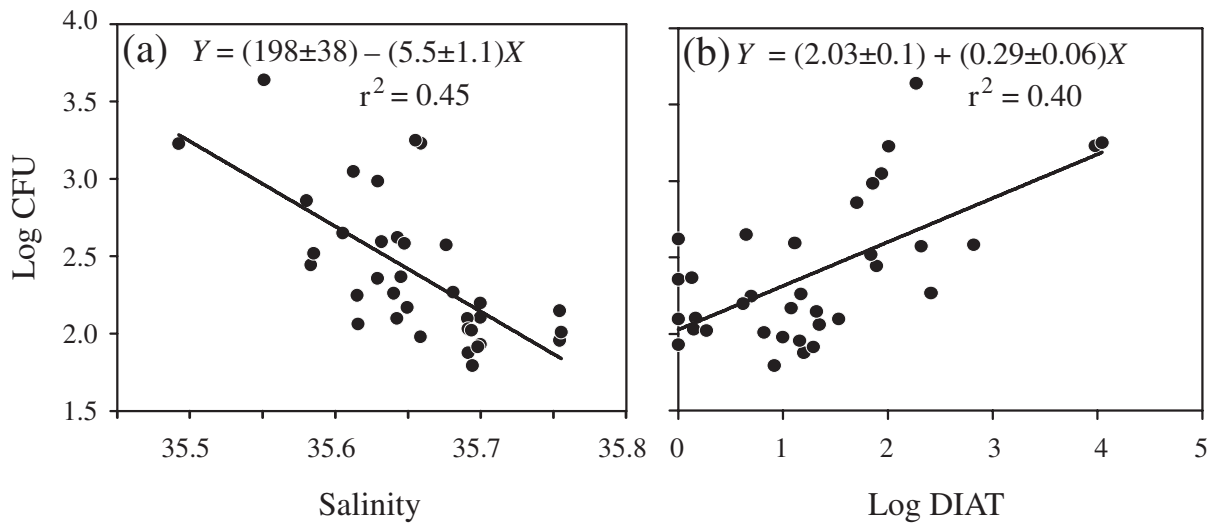

Fig. 6. (a) Salinity and (b) log of diatom abundance vs. log of abundance of colony forming units (CFU). Equations are linear regressions $(p<0.001)$ 
gest that both temperature and DOM may control bacterial abundance; temperature affects the response time and affinity of bacteria for DOM. Donachie et al. (2001) showed that uptake rates of DOM are also affected by the type of available nitrogen. Ammonium significantly enhanced glucose uptake.

BA and abundance of most biological groups showed a tendency to increase southward and with distance from the shore (Table 2). Although greater accumulation of bacteria towards the south along the Galician coast may, in part, result from the offshore export of high primary production within the Rías Baixas, which is then advected south (Castro et al. 1994, 2000), the highest observed variability in bacterial abundance was related with coastal-ocean gradients. This might be related to the different aging of plankton communities along these coastal-ocean gradients, with fresh phytoplankton populations dominating in coastal waters where the influence of upwelling was stronger and the presence of a more evolved community offshore where trophic relationships would attain higher importance.

Although we found significant relationships between BA and several variables (Table 4), which could suggest that BA was regulated simultaneously by temperature and bottom-up (the relationships with phytoplankton components and $\mathrm{Chl}$ ) and top-down processes (the relationships with HPF and HNF), the strong covariation among variables (Table 3 ) impedes such a direct explanation. The most obvious case was temperature, which accounted for $51 \%$ of the BA variability (Table 4) but also showed a positive covariation with almost all biological variables, and a negative covariation with nutrients (Table 3). Although temperature did not appear to be a significant factor in the explained variability in BA (Table 5), it may have indirectly affected variations in BA by promoting phytoplankton growth through the incipient stratification of surface waters, which then caused nutrient depletion.

The significant relationship between BA and phytoplankton (ANF, Chl) and HNF ( $61 \%$ of the BA variability explained by ANF; Table 5) suggests that bacterial abundance in the NW Iberian margin in spring during the cruise GALICIA XI was largely controlled by resource availability. Grazing control on bacterial abundance by HNF, as suggested by the multiple regression and by the relationship between HNF and BA (Fig 5b), should be of lesser importance than the supply of resources, since only $7 \%$ of the BA variability could be explained by HNF in the multiple regression. Resources would be mainly supplied by piconanophytoplankton with lesser contribution by diatoms, as indicated by the slopes of the 2 equations describing the relationship between $\mathrm{BA}$ and $\mathrm{Chl}$ (Fig. $5 \mathrm{c} ; 1.06 \times 10^{12}$ bacteria $\mathrm{mg} \mathrm{Chl}^{-1}$ for ocean sam- ples and $0.08 \times 10^{12}$ bacteria $\mathrm{mg} \mathrm{Chl}^{-1}$ for coastal samples). These slopes suggest that ocean waters, where ANF dominated, were 10 times more efficient than coastal waters, with their diatom dominance, at supplying resources for bacterial growth. Although it could be argued that the lower slope might result from stronger grazing pressure on coastal bacteria (Barbosa et al. 2001), the relationship between HNF and BA when analysed for these samples separately $(\log \mathrm{BA}=$ $4.76 \pm 0.19+0.41 \pm 0.06 \log$ HNF) did not change significantly from that obtained from all samples (Table 4).

This may, then, suggest that there is a higher availability of resources for bacteria in the open ocean waters than in coastal waters. Resources would be supplied directly by phytoplankton through DOM exudation (Teira et al. 2001, Morán et al. 2002) and/or indirectly through DOM generated from trophic relationships (Joint et al. 2001). Higher ammonium and lower nitrate concentration at the oceanic stations (Table 2, Fig. 2c), where pico- and nanophytoplankton were more abundant, suggests that recycling of organic matter was in fact taking place. Recycling processes would partially occur by grazing, which in turn is considered an important source of DOM (Strom et al. 1997, Nagata 2000). In contrast, new nutrients injected by upwelling to coastal waters (Table 2, Fig. 2c, Fig. 3) would have favoured diatom growth over heterotrophy. Recently, Ning et al. (2005) also reported analogous results for the South China Sea, where they found a stronger coupling between bacterioplankton and SYN in offshore than in coastal waters.

Constant bacterial numbers around 2 to $2.5 \times 10^{6}$ bacteria $\mathrm{ml}^{-1}$ at abundances higher than 2500 ANF $\mathrm{ml}^{-1}$ (equation in Fig. 5a) and $\mathrm{Chl}$ concentrations higher than $1.72 \mathrm{mg} \mathrm{m}^{-3}$ in the ocean stations (equation 1 in Fig. 5c) correspond to those reported by Li et al. (2004) as the upper macroecological limit of bacterial abundance in the ocean, beyond which a transition from bottom-up to top-down control of BA would be expected. The exponential relationship between BA and HNF (Fig. 5b), with BA remaining virtually constant at $\sim 2 \times 10^{6}$ bacteria $\mathrm{ml}^{-1}$ for the highest $\mathrm{HNF}$ abundances, suggests that at these HNF abundances all bacterial production would be removed by HNF. This would indicate a possible transition towards topdown control of bacteria at the highest BA. The same inference can be attained when the relationship between BA and HNF is analysed in the framework of the model proposed by Gasol (1994). According to this model, the importance of the bottom-up/top-down control of HNF/BA would be greater for a shorter distance between the actual position of the points and a line defining the maximum attainable HNF abundance (MAA) for a given BA. Fig. 7 shows this relationship, in 


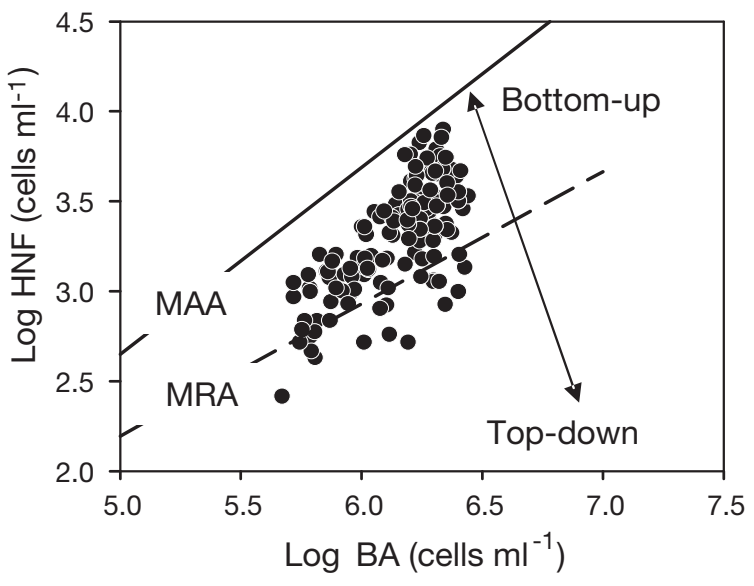

Fig. 7. Log of bacterial abundance (BA) vs. log of HNF abundance depicted in the framework proposed by Gasol (1994) for the assessment of top-down vs. bottom-up control of HNF abundance. MAA and MRA lines correspond to maximum attainable abundance and maximum realised abundance of HNF, respectively. Points close to the MAA line would indicate bottom-up control of HNF abundance and therefore topdown control of BA. Points on the MRA line and far below this line would point to a higher importance of top-down/bottomup control of abundances of $\mathrm{HNF} / \mathrm{bacteria}$

which a shift in the relative position of the points is evident. Thus, while the points that defined low bacteria and HNF abundances situated well below the MAA line, several points that corresponded to high BA were placed close to it. This suggests a greater importance of top-down control of bacteria for the highest BA (Gasol 1994). Regardless of this, the use of resources other than bacteria by HNF (Gasol \& Vaqué 1993, Tranvik et al. 1993) would also result in the points being closer to, or even above, the MAA line, implying that bacteria were controlled by factors other than HNF grazing. Although temperature can effectively limit bacterial growth through affecting the affinity of bacteria for DOM (Kirchman \& Rich 1997), the action of grazers other than HNF and viral lyses should not be disregarded. Phagotrophy by ANF, which is usually more important at high bacterial densities (Sanders et al. 1990) and during low nutrient levels (Arenovski et al. 1995), would also contribute to this control of bacteria at these high abundances.

\section{Control of CFU abundance}

Comparing CFU with physical and biological variables revealed that low seawater salinity and high diatom abundance accounted for $67 \%$ of the variance in CFU. A decreasing shoreward trend in salinity might indicate the importance of terrestrial runoff in supplying the inshore with fresh water and fertilizers, as well as with a significant fraction of halotolerant soil bacteria such as spore formers in the Ría de Vigo (Zdanowski \& Figueiras 1997). However, CFU were more abundant in coastal waters where large diatoms dominated the phytoplankton in response to stronger upwelling. Previous studies in the Ría de Vigo (Zdanowski \& Figueiras 1999) have also shown positive relationships between CFU and upwelling, when diatoms dominated the phytoplankton.

Although CFU is only a small fraction of total heterotrophic bacterioplankton (Table 1), Zdanowski \& Donachie's (1993) experiments of seawater enrichment with particulate matter (detritus) showed a significant increase of the CFU:BA ratio. Thus a high abundance of CFU might indicate that bacteria are more able to exploit organic matter aggregates. The correlation of CFU with diatom abundance would therefore not be surprising, since large diatoms during spring or upwelling conditions may also form aggregates. We could conclude after Unanue et al. (1992) that CFU abundance follows patterns that differ from those of total bacterioplankton, which co-vary with DOM, while the number of CFU depends on the concentration of large particles of organic matter and less on changes in DOM.

\section{CONCLUSIONS}

Bacterial abundance in the NW Iberian margin in spring appeared to be largely controlled by the resources provided by phytoplankton, specifically from autotrophic nanoflagellates. Though diatoms had a lesser importance than autotrophic nanoflagellates in supplying resources for heterotrophic bacterioplankton, they showed a conspicuous relationship with colony forming units, which would suggest an association between diatoms and those bacteria that are more able to degrade large particulate matter. The relationship between the abundances of total heterotrophic bacterioplankton and autotrotrophic nanoflagellates in the oceanic waters suggested a shift from bottom-up to top-down control of bacterial abundance at autotrophic nanoflagellate abundances higher than 2500 cells $\mathrm{ml}^{-1}$. This shift occurred at a $\mathrm{Chl}$ a concentration of approximately $2 \mathrm{mg} \mathrm{m}^{-3}$.

Acknowledgements. We thank our colleagues who participated in the GALICIA XI cruise. Special thanks to Dr. G. H. Tilstone and Dr. S. Donachie for useful suggestions and for editing the manuscript. We also thank 2 anonymous reviewers for their comments, which considerably improved the manuscript. This work was supported by the EU project MAST-CT90-0017 (The control of phytoplankton dominance). M.K.Z. thanks the Ministerio de Educación y Ciencia and Ministerio de Asuntos Exteriores of Spain for financial support. B.G.C. was funded by an I3P fellowship of CSIC-ESF. 


\section{LITERATURE CITED}

Álvarez-Salgado XA, Doval MD, Pérez FF (1999) Dissolved organic matter in shelf waters off the Ría de Vigo (NW Iberian upwelling system). J Mar Syst 18:383-394

Álvarez-Salgado XA, Gago J, Míguez BM, Gilcoto M, Pérez FF (2000) Surface waters of the NW Iberian margin: upwelling on the shelf versus outwelling of upwelled waters from the Rías Baixas. Estuar Coast Shelf Sci 51: 821-837

Arenovski AL, Lim EL, Caron DA (1995) Mixotrophic nanoplankton in oligotrophic surface waters of the Sargasso Sea may employ phagotrophy to obtain major nutrients. J Plankton Res 17:801-820

Barbosa AB, Galvao HM, Mendes PA, Álvarez-Salgado XA, Figueiras FG, Joint I (2001) Short-term variability of heterotrophic bacterioplankton during upwelling off the NW Iberian margin. Progr Oceanogr 51:339-359

Castro CG, Pérez FF, Álvarez-Salgado XA, Rosón G, Ríos AF (1994) Hydrographic conditions associated with the relaxation of an upwelling event off the Galician coast (NW Spain). J Geophys Res 99:5135-5147

Castro CG, Pérez FF, Alvarez-Salgado XA, Fraga F (2000) Coupling between the thermohaline, chemical and biological fields during two contrasting upwelling events off NW Iberian Peninsula. Cont Shelf Res 20:189-210

Cole JJ, Findlay S, Pace ML (1988) Bacterial production in fresh and saltwater ecosystems: a cross-system overview. Mar Ecol Prog Ser 43:1-10

Currie DJ (1990) Large-scale variability and interactions among phytoplankton, bacterioplankton, and phosphorous. Limnol Oceanogr 35:1437-1455

del Giorgio PA, Cole JJ (1998) Bacterial growth efficiency in natural aquatic systems. Annu Rev Ecol Syst 29:503-541

Donachie SP, Christian JR, Karl DM (2001) Nutrient regulation of bacterial production and ectoenzyme activities in the subtropical North Pacific Ocean. Deep-Sea Res II 48: $1719-1732$

Fraga F (1976) Fotosíntesis en la ría de Vigo. Inv Pesq 40: 151-167

Fuhrman JA (1992) Bacterioplankton roles in cycling of organic matter: the microbial food web. In: Falkowski PG, Woodhead AD (eds) Primary productivity and biogeochemical cycles in the sea. Plenum Press, New York, p 361-383

Gasol JM (1994) A framework for the assessment of top-down vs bottom-up control of heterotrophic nanoflagellate abundance. Mar Ecol Prog Ser 113:291-300

Gasol JM, Duarte CM (2000) Comparative analyses in aquatic microbial ecology: how far they go? FEMS Microb Ecol 31: 99-106

Gasol JM, Vaqué D (1993) Lack of coupling between heterotrophic nanoflagellates and bacteria: A general phenomenon across aquatic systems? Limnol Oceanogr 38:657-665

Grasshoff K, Johannsen H (1972) A new sensitive and direct method for the automatic determination of ammonia in seawater. J Cons Int Explor Mer 34:516-521

Hansen HP, Grasshoff K (1983) Automated chemical analysis. In: Grasshoff K, Ehrhardt M, Kremling K (eds) Methods of seawater analysis. Verlag Chemie, Weinheim, p 347-379

Hanson RB, Alvarez-Ossorio MT, Cal R, Campos MJ, Roman M, Santiago G, Varela M, Yoder JA (1986) Plankton response following a spring upwelling event in the Ria de Arosa, Spain. Mar Ecol Prog Ser 32:101-113

Joint I, Inall M, Torres R, Figueiras FG, Álvarez-Salgado XA, Rees AP, Woodward EMS (2001) Two lagrangian experiments in the Iberian upwelling system: tracking an upwelling event and an off-shore filament. Progr Oceanogr 51:221-248

Joint I, Groom SB, Wollast R, Chou L, Tilstone GH, Figueiras FG, Loijens M, Smyth TJ (2002) The response of phytoplankton production to periodic upwelling and relaxation events at the Iberian shelf break: estimates by the ${ }^{14} \mathrm{C}$ method and by satellite remote sensing. J Mar Syst 32: $219-238$

Kirchman DL, Rich JH (1997) Regulation of bacterial growth rates by dissolved organic carbon and temperature in the Equatorial Pacific Ocean. Microb Ecol 33:11-20

Li WKW (2002) Macroecological patterns of phytoplankton in the northwestern North Atlantic Ocean. Nature 419: $154-157$

Li WKW, Head EJH, Harrison WG (2004) Macroecological limits of heterotrophic bacterial abundance in the ocean. Deep-Sea Res I 51:1529-1540

Moncoiffé G, Álvarez-Salgado XA, Figueiras FG, Savidge G (2000) Seasonal and short time-scale dynamics of microplankton community production and respiration in an inshore upwelling system. Mar Ecol Prog Ser 196:111-126

Morán XAG, Gasol JM, Pedrós-Alió C, Estrada M (2002) Partitioning of phytoplanktonic organic carbon production and bacterial production along a coastal-offshore gradient in the NE Atlantic during different hydrographic regimes. Mar Ecol Prog Ser 29:239-252

Mouriño C, Fraga F (1985) Determinación de nitratos en agua de mar Inv Pesq 49:81-96

Nagata T (2000) Production mechanisms of dissolved organic matter. In: Kirchman DL (ed) Microbial ecology of the oceans. Wiley \& Sons, New York, p 121-152

Ning X, Li WKW, Cai Y, Shi J (2005) Comparative analysis of bacterioplankton and phytoplankton in three ecological provinces of the northern South China Sea. Mar Ecol Prog Ser 293:17-28

Porter KG, Feig YS (1980) The use of DAPI for identifying and counting aquatic microflora. Limnol Oceanogr 25:943-948

Proctor LM, Fuhrman JA (1990) Viral mortality of marine bacteria and cyanobacteria. Nature 343:60-62

Prego R, Fraga F, Ríos AF (1990) Water interchange between the Ría of Vigo and the coastal shelf. Sci Mar 54:95-100

Sanders RW, Porter KG, Caron DA (1990) Relationship between phototrophy and phagotrophy in the mixotrophic Chrysophyte Poterioochromonas malhamensis. Microb Ecol 19:97-109

Sherr EB, Sherr BF (1987) High rates of consumption of bacteria by pelagic ciliates. Nature 325:710-711

Smith DC, Simon M, Alldredge AL, Azam F (1992) Intense hydrolytic enzyme activity on marine aggregates and implications for rapid particle dissolution. Nature 359:139-142

Strom LS, Benner R, Ziegler S, Gagg MJ (1997) Planktonic grazers are potentially important source of marine dissolved organic carbon. Limnol Oceanogr 42:1364-1374

Teira E, Serret P, Fernández E (2001) Phytoplankton sizestructure, particulate and dissolved organic carbon production and oxygen fluxes through microbial communities in the NW Iberian coastal transition zone. Mar Ecol Prog Ser 219:65-83

Tenore KR, Alonso-Noval M, Alvarez-Ossorio M, Atkinson LP and 15 others (1995) Fisheries and oceanography off Galicia, NW Spain: Mesoscale spatial and temporal changes in physical processes and resultant patterns of biological productivity. J Geophys Res 100:10943-10966

Tilstone GH, Figueiras FG, Fermín EG, Arbones B (1999) Significance of nanophytoplankton photosynthesis and primary production in a coastal upwelling system (Ría de Vigo, NW Spain). Mar Ecol Prog Ser 183:13-27 
Tilstone GH, Figueiras FG, Lorenzo LM, Arbones B (2003) Phytoplankton composition, photosynthesis and primary production during different hydrographic conditions at the NW Iberian upwelling system. Mar Ecol Prog Ser 252: 89-104

Tranvik A, Sherr EB, Sherr BF (1993) Uptake and utilization of 'colloidal DOM' by heterotrophic flagellates in seawater. Mar Ecol Prog Ser 92:301-309

Unanue M, Ayo B, Azúa I, Barcina I, Iriberri J (1992) Temporal variability of attached and free-living bacteria in coastal waters. Microb Ecol 23:27-39

Valencia J, Abalde J, Bode A, Cid A and 5 others (2003) Variation in planktonic bacterial biomass and production, and phytoplankton blooms off A Coruña (NW Spain). Sci Mar 67:143-157

Weimbauer MG, Peduzzi P (1995) Significance of viruses versus heterotrophic nanoflagellates for controlling bacterial abundance in the northern Adriatic Sea. J Plankton Res 17:1851-1856

White PA, Kalff J, Rasmussen JB, Gasol JM (1991) The effect of temperature and algal biomass on bacterial production and specific growth rate in freshwater and marine habi-

Editorial responsibility: William K. W. Li,

Dartmouth, Nova Scotia, Canada tats. Microb Ecol 21:99-118

Wollast R (1998) Evaluation and comparison of the global carbon cycle in the coastal zone and in the open ocean. In: Brink KH, Robinson AR (eds) The sea. Vol 10. John Wiley \& Sons, New York, p 213-252

Yentsch CS, Menzel DW (1963) A method for the determination of phytoplankton chlorophyll and phaeophytin by fluorescence. Deep-Sea Res 10:221-231

Zdanowski MK, Donachie SP (1993) Bacteria in the sea-ice zone between Elephant Island and the South Orkneys during the Polish sea-ice zone expedition, December 1988 to January 1989. Polar Biol 13:245-254

Zdanowski MK, Figueiras FG (1997) Relationships between bacterial abundance, other biota, and hydrographic variability in the Ría de Vigo, Spain. Mar Ecol Prog Ser 147: 257-267

Zdanowski MK, Figueiras FG (1999) CFU bacterial fraction in the estuarine upwelling ecosystem of Ría de Vigo, Spain: variability in abundance and their ecophysiological description. Mar Ecol Prog Ser 182:1-15

ZoBell CE (1941) Studies on marine bacteria. 1. The cultural requirements of heterotrophic aerobes. J Mar Res 4:42-75

Submitted: July 19, 2005; Accepted: February 13, 2006

Proofs received from author(s): July 10, 2006 